\title{
Prevalence, Patterns and Predictors of physical activity in Urban Population of Bhubaneswar smart city, India
}

Running Head: Physical inactivity in a smart city

Satyajit Mohanty ${ }_{5 \wedge}^{1}$, Jyotiranjan Sahoo $^{2}$, Epari Venkatarao ${ }^{3}$, G Ganesh Shankar ${ }^{4}$, Sandeep Kumar Panigrahi ${ }^{5^{\wedge}}$

${ }^{1} \mathrm{PhD}$ Student, Community Medicine Department, IMS and SUM Hospital, Siksha O Anusandhan deemed to be University, Bhubaneswar, India - 751003. Email: satyajit.mohanty74@gmail.com

${ }^{2}$ Associate Professor, Community Medicine Department, IMS and SUM Hospital, Siksha O Anusandhan deemed to be University, Bhubaneswar, India - 751003. Email: dr.jyotiranjan@gmail.com

${ }^{3}$ Professor, Community Medicine Department, IMS and SUM Hospital, Siksha O Anusandhan deemed to be University, Bhubaneswar, India - 751003. Email: e.venkata.rao@gmail.com

${ }^{4}$ Lecturer in physiotherapy, Composite regional center for skill development, rehabilitation, and empowerment of persons with disabilities, Lucknow 226017. Email: shankarpt@ rediffmail.com

${ }^{5}$ Associate Professor, Community Medicine Department, IMS and SUM Hospital, Siksha O Anusandhan deemed to be University, Bhubaneswar, India - 751003. Email: dr.sandeepvss@gmail.com

${ }^{\wedge}$ Corresponding author:

Dr. Sandeep Kumar Panigrahi

Associate Professor, Community Medicine Department, IMS and SUM Hospital,

Siksha O Anusandhan deemed to be University, Bhubaneswar, Odisha, India -751003

Email: $\underline{\text { dr.sandeepvss@ gmail.com ; sandeeppanigrahi@ hotmail.com }}$ Mobile: +919439369093 
medRxiv preprint doi: https://doi.org/10.1101/2020.11.28.20240358; this version posted January 3, 2021. The copyright holder for this preprint (which was not certified by peer review) is the author/funder, who has granted medRxiv a license to display the preprint in perpetuity.

It is made available under a CC-BY-NC-ND 4.0 International license .

\begin{abstract}
Background: Physical inactivity is a risk factor for mortality and morbidity. Physical activity and its predictors among urban population in this part of the country was unknown. Finding physical inactivity as a cause of current noncommunicable diseases (NCD) is difficult.
\end{abstract}

\title{
Objectives:
}

To find out the prevalence, patterns and predictors of physical activity in urban population, and investigate its causal relationship with NCD.

Materials and methods: It was a cross-sectional study using cluster random sampling. Sample size was 1203 . Socio-demographic, health profile, physical activity levels, and stage of change for physical activity behaviour were collected. was used for analysis. Logistic regression and marginal structural model analysis (by IPTW) were done using IBM SPSS 20.0. Statistical significance were tested at $\mathrm{p}=0.05$.

Results: 1221 subjects participated. Mean age was 35.25 years. $71.9 \%$ were physically inactive, $15.9 \%$ practised 'yogasana'. General caste, presence of NCD, being in a static stage of change and a yogassana practitioner influenced physical activity positively. Physical inactivity had 1.54 times higher odds for NCD and was statistically significant.

Conclusion: Prevalence of physical activity was low. Physical inactivity was a causative factor for NCD.

Keywords: behaviour; chronic disease; sedentary behaviour; social class; 


\section{Introduction:}

Physical activity (PA) is defined as any bodily movement produced by skeletal muscles that require energy expenditure, which includes structured activity programs such as exercises, and activities undertaken while working, playing, and carrying out household works [1]. Regular PA has been found to improve physiological functioning, quality of life, social and work participation [2]. On the other hand unhealthy dietary habits, physical inactivity and genetic predisposition can result in worsening of several chronic conditions including type 2 diabetes mellitus, and cognitive disorders [3,4]. Insufficient physical activity is considered as one of the leading risk factors for global mortality and increases the disability-adjusted life years (DALYs) [5]. Physical inactivity is therefore considered a global public health problem [6]. Considering the overall benefits of PA, the feasibility to engage and low cost, the WHO has recommended a cumulative engagement of minimum 150 minutes per week of moderate physical activity [7]. Maintaining physical activity throughout life is considered an important public health objective $[2,8]$.

Despite the documented benefits and importance, $23 \%$ of males and $32 \%$ females above 18 years of age are physically inactive around the world [7] and there is a global trend towards engaging in sedentary behaviours [9]. Compared to global estimates, Indians are found to be sedentary and less physically active. A multi-centre study conducted in four regions of India and involving 14,227 participants concluded that large percentage of people in India are inactive and less than $10 \%$ population engages in recreational PA [10]. Another work reported that the exercise intensities undertaken do not meet the global recommended intensities, even in those who undertake leisure time PA [11].

Apart from traditional PAs, there is a necessity to evaluate the prevalence of people who follow other complementary and alternative therapies such as yoga for engaging in PA, as it 
medRxiv preprint doi: https://doi.org/10.1101/2020.11.28.20240358; this version posted January 3, 2021. The copyright holder for this preprint

promotes holistic health. Though yoga may not be plainly compared to physical exercises, yoga interventions are equally effective to exercises in improving positive outcomes [12-14].

This data on the acceptability of Yoga as a tool may be important to policy makers to establish yoga wellness centers and provide yoga resources to the general public. Recognizing the importance of PA, the Government of India has launched the 'Fit India movement' [15] and the 'Khelo India' programme [16] to promote fitness as a way to create a healthy society and strong country.

Why few people are physically active and others are inactive is an intriguing question. A number of theoretical models and numerous studies from western countries attempted to look into this aspect [17-19]. Past exercise behaviours, perceived self-efficacy, social support, self-confidence, access to facilities, physical environment, gender and socio-economic status are identified as some factors that can influence PA behaviour [18]. Lower levels of motivation, limited free time, fear of falling, cost, transportation, pain, and lack of enjoyment are seen as barriers to participating in regular PA [20-22]. A report from Kenya found associations between low levels of PA and the demographic and social changes that prevail there [23]. However, no previous work has specifically looked into the PA patterns and the factors that predict PA among the urban population in Odisha state of India. This may be deemed important as the factors that predict PA patterns may be different across cultures and data on PA are important to formulate action plans for the promotion of PA for a region. The objective of this study was therefore to evaluate the PA patterns and predict the factors that influence the PA pattern in an urban setting in Bhubaneswar city of Odisha, India.

NCDs account for $61 \%$ of total deaths in India and are attributed to lifestyle-related risk factors such as tobacco use, physical inactivity, alcohol consumption, and obesity [24,25]. A 2010 cross sectional study identified tobacco and alcohol use, low intake of fruit and 
medRxiv preprint doi: https://doi.org/10.1101/2020.11.28.20240358; this version posted January 3, 2021. The copyright holder for this preprint (which was not certified by peer review) is the author/funder, who has granted medRxiv a license to display the preprint in perpetuity.

It is made available under a CC-BY-NC-ND 4.0 International license .

vegetables, and underweight as risk factors amongst the lower socioeconomic positions in rural Indians , while obesity, dyslipidaemia, and diabetes in men and hypertension in women as the more prevalent risk factors for NCDS for those in higher socioeconomic positions [26]. Though promoting better urban design to increase physical activity and reducing sedentary lifestyles in Urban India has been put forward as a strategy to reduce the risk of NCDs [27], we could not identify literature that have examined the relationship between physical activity and NCDs in India either as an independent risk factor or when controlled for other variables. Therefore, we proposed to use inverse probability of treatment weighting (IPTW) method to investigate the relationship between physical activity and prevalence of NCDs in a large urban based study.

\section{Objectives:}

1. To find out the prevalence and patterns of physical activity in urban population.

2. To investigate the relationship of non-communicable disease with physical inactivity.

\section{Methods:}

The study participants were recruited from Bhubaneswar, the capital city of State of Odisha, India. This cross-sectional survey was conducted from February to August 2019 involving adults of both sexes aged 18 years and above. Bhubaneshwar has a population of $8,85,363$ residing in 1,97,661 households spread over 67 administrative wards and about $18.5 \%$ of the population reside in the slums[28,29].

The sample size was calculated based on previous estimates of the prevalence of physical activity (45.6\%) in an urban setting[30]. Using a $Z$ value of 1.96 at $95 \%$ confidence, absolute allowable error at $5 \%$ with an effect size of 3 , the sample size was calculated to be 1203 to achieve $80 \%$ power. 
medRxiv preprint doi: https://doi.org/10.1101/2020.11.28.20240358; this version posted January 3, 2021. The copyright holder for this preprint

30 administrative wards were randomly selected and the households were selected using a systematic random sampling method. Door-to-door visits were conducted between 2 PM to 7 PM to collect data by 2 enumerators. If a household refused to participate, the data was collected from the immediate next household. Only one response per household was documented. As the objective of study was to document the prevailing PA patterns, individuals with physical and mental disabilities who could not undergo regular PA otherwise were excluded from the study. Approval was obtained from the institute ethics committee prior to study commencement (DMR/IMS-SH/SOA/170066) and verbal informed consent was obtained from all participants in the local language. Though participants in the study were public, yet it was not appropriate or possible to involve patients or the public in the design, or conduct, or reporting, or dissemination plans of our research.

All the data were collected by the first author while another author oversaw the procedure. A pre-tested, semi-structured questionnaire was used to collect data on socio-demographic parameters related to age, religion, caste, marital status, education, occupation, family size, and monthly family income. Respondents were asked if they were suffering from any chronic diseases such as hypertension, diabetes, cardiovascular disease, asthma, and other chronic respiratory problems. Questions pertaining to addiction to alcohol, and smoking etc were collected along with factors that promoted PA. The behavioural aspects related to stages of change to PA promotion was evaluated using the Prochaska and DiClemente's model [31]. The International physical activity questionnaire (IPAQ)-short from was used to assess the PA level of the participants. The IPAQ- short form is a 7-day physical activity recall questionnaire which has seven questions, related to frequency, duration and intensity of PA[32]. The IPAQ- short form is found to be valid and reliable [33-35]. A question on the current practice of yoga was asked. The average time taken to complete the questionnaire was 15 minutes. 
medRxiv preprint doi: https://doi.org/10.1101/2020.11.28.20240358; this version posted January 3, 2021. The copyright holder for this preprint (which was not certified by peer review) is the author/funder, who has granted medRxiv a license to display the preprint in perpetuity.

It is made available under a CC-BY-NC-ND 4.0 International license .

\section{Classifications used:}

The socioeconomic status (SES) of the participants was determined using modified BG Prasad SES scale (2018) based on per capita monthly income. The SES was classified into five groups, namely lower, upper-lower, middle, upper-middle and upper class[36]. Chronic diseases were classified as per the International statistical classification of diseases and related health problems- 10th revision (ICD-10) [37]. The state of change with respect to PA/exercise was grouped into either static (Pre-contemplation and Relapse) or dynamic (Contemplation, Decision, Action, and Maintenance) stages [38]. Based on the IPAQ scores, PA levels were classified as low, moderate and high. Participants who were classified under moderate PA and high PA were considered to be 'physically active' for the purpose of this study. Respondents classified as having low PA was considered as 'physically inactive'.

\section{Statistical analysis:}

Statistical analyses were performed using the SPSS software version 20 (IBM SPSS). Categorical variables were expressed in terms of frequency and percentages. Estimates were expressed as mean \pm standard deviation or proportions. Association between two categorical variables was tested using the Chi-squared test. Presence of gender bias was tested during analysis. Logistic regression analyses were used to compute adjusted odds ratios for each variable. $P$-values of less than 0.05 were considered significant.

The causality of chronic disease by 'physically inactive' was tested through inverse probability of treatment weighting (IPTW) using marginal structural model (MSM) using a Generalized Estimating Equation (GEE). The covariates used to generate the propensity score was the same variables found to be associated with physically activity status in univariate analysis (with $\mathrm{p}$ value of less than 0.20). First the weighted predicted values (inverse propensity score) were calculated for physical activity categories which was later normalized 
medRxiv preprint doi: https://doi.org/10.1101/2020.11.28.20240358; this version posted January 3, 2021. The copyright holder for this preprint (which was not certified by peer review) is the author/funder, who has granted medRxiv a license to display the preprint in perpetuity.

It is made available under a CC-BY-NC-ND 4.0 International license .

through robust estimator for the covariance matrix applying generalized estimating equations for predicting association of insufficiently physically active to that of chronic diseases.

\section{Results:}

A total of 1221 study participants were interviewed from the selected thirty clusters. After data cleaning, a total 1125 cases were included for analysis. Mean age of the study participants was 35.25 ( \pm SD 10.72) years. Males and females gender representation in the group was not significantly different $(\mathrm{p}=0.350)$. The average distance of the nearest public exercise facility from home was 496.81 ( \pm SD 238.73) meters with a maximum distance of 1500 meters. Majority (87.4\%) of the study population was in the dynamic stage of exercise behaviour change according to the Prochaska and DiClemente model. A total of 809 (71.9\%) of the respondents were classified as physically inactive. Rest $316(28.1 \%)$ of the respondents were found to be physically active among and them only $11(1 \%)$ were involved in high PA. $179(15.9 \%)$ respondents practised 'yogasana' (Table 1). Among the practitioners of yoga, 68 (32.8\%) met recommended standards of PA.

Mean days/week spent in walking was 1.98 (95\% CI: $1.80-1.16)$ with mean walk duration was 17.56 (95\% CI: 16.76 - 18.37) mins/day. Mean days/week spend in 'moderate intensity' PA was 0.33 (95\% CI: 0.25 - 0.41) with mean 'moderate intensity' PA duration (min) /day was 12.56 (95\% CI: 11.88 - 13.25). Mean days/week spend in 'high intensity' PA was 0.19 (95\% CI: $0.13-0.25)$ with mean 'high intensity' PA duration (min)/day was 11.44 (95\% CI: $10.92-11.95)$.

Table 1: Characteristics of the study population $(n=1125)$

\begin{tabular}{lccccc}
\hline Variables & $\begin{array}{c}\text { Total subjects } \\
(\mathbf{n}, \boldsymbol{\%})\end{array}$ & $\begin{array}{c}\text { Physically } \\
\text { inactive } \\
(\mathbf{n}, \boldsymbol{\%})\end{array}$ & $\begin{array}{c}\text { Physically } \\
\text { active } \\
(\mathbf{n}, \boldsymbol{\%})\end{array}$ & $\begin{array}{c}\text { Odds ratio } \\
(\mathbf{9 5 \%} \text { CI) }\end{array}$ & $\begin{array}{c}\text { P- } \\
\text { Value }\end{array}$ \\
\hline Age & & & & & \\
\hline & & & & 0.89 & 0.593 \\
& & & & $(0.59-1.34)$ & \\
\hline
\end{tabular}


medRxiv preprint doi: https://doi.org/10.1101/2020.11.28.20240358; this version posted January 3, 2021. The copyright holder for this preprint (which was not certified by peer review) is the author/funder, who has granted medRxiv a license to display the preprint in perpetuity.

It is made available under a CC-BY-NC-ND 4.0 International license .

\begin{tabular}{|c|c|c|c|c|c|}
\hline 30-39 years & $324(28.8 \%)$ & $247(76.2)$ & $77(23.8)$ & $\begin{array}{c}0.64 \\
(0.42-0.99)\end{array}$ & 0.047 \\
\hline 40-49 years & $271(24.1 \%)$ & $195(72.0)$ & $76(28.0)$ & $\begin{array}{c}0.52 \\
(0.73-1.24)\end{array}$ & 0.342 \\
\hline $50-59$ years & $151(13.4 \%)$ & $102(67.5)$ & $49(32.5)$ & Ref & -- \\
\hline \multicolumn{6}{|l|}{ Gender } \\
\hline Male & $683(55.9 \%)$ & $423(70.7)$ & $175(29.3)$ & $\begin{array}{c}1.13 \\
(0.87-1.47) \\
\end{array}$ & 0.350 \\
\hline Female & $538(44.1 \%)$ & $386(73.2)$ & $141(26.8)$ & Ref & - \\
\hline \multicolumn{6}{|l|}{ Religion } \\
\hline Hindu & $1053(93.6 \%)$ & $758(72.0)$ & $295(28.0)$ & $\begin{array}{c}0.94 \\
(0.55-1.59)\end{array}$ & 0.833 \\
\hline Non-Hindu & $72(6.4 \%)$ & $51(70.8)$ & $21(29.2)$ & Ref & -- \\
\hline \multicolumn{6}{|l|}{ Caste } \\
\hline General & $694(61.7 \%)$ & $484(69.7)$ & $210(30.3)$ & $\begin{array}{c}1.33 \\
(1.01-1.74)\end{array}$ & 0.040 \\
\hline Others & $431(38.3 \%)$ & $325(75.4)$ & $106(24.6)$ & $R e f$ & -- \\
\hline \multicolumn{6}{|l|}{ Marital } \\
\hline Unmarried & $249(22.1 \%)$ & $160(64.3)$ & $89(35.7)$ & $\begin{array}{c}1.78 \\
(0.63-5.02)\end{array}$ & 0.276 \\
\hline Married & $855(76.0 \%)$ & $633(74.0)$ & $222(26.0)$ & $\begin{array}{c}1.12 \\
(0.40-3.09)\end{array}$ & 0.824 \\
\hline $\begin{array}{l}\text { Separated/wid } \\
\text { ow(er) }\end{array}$ & $21(1.9 \%)$ & $16(76.2)$ & $5(23.8)$ & $\operatorname{Ref}$ & -- \\
\hline \multicolumn{6}{|l|}{ Education } \\
\hline $\begin{array}{l}\text { Above } \\
\text { graduation }\end{array}$ & $111(9.9 \%)$ & $74(66.7)$ & $37(33.3)$ & $\begin{array}{c}1.58 \\
(1.02-2.44)\end{array}$ & 0.040 \\
\hline $\begin{array}{l}\text { Up to } \\
\text { graduation }\end{array}$ & $423(37.6 \%)$ & $286(67.6)$ & $137(32.4)$ & $\begin{array}{c}1.51 \\
(1.14-1.99)\end{array}$ & 0.003 \\
\hline $\begin{array}{l}\text { Up to high } \\
\text { school }\end{array}$ & $591(52.5 \%)$ & 449 (76.0) & $142(24.0)$ & $\operatorname{Ref}$ & -- \\
\hline \multicolumn{6}{|l|}{ Occupation } \\
\hline $\begin{array}{l}\text { Gainfully } \\
\text { employed }\end{array}$ & $575(51.1 \%)$ & $424(73.7)$ & $151(26.3)$ & $\begin{array}{c}1.48 \\
(0.59-3.68) \\
\end{array}$ & 0.395 \\
\hline $\begin{array}{l}\text { Non- } \\
\text { gainfully } \\
\text { employed }\end{array}$ & $519(46.1 \%)$ & $360(69.4)$ & $149(30.6)$ & $\begin{array}{c}1.84 \\
(0.74-4.57)\end{array}$ & 0.189 \\
\hline $\begin{array}{l}\text { Unemployed/ } \\
\text { retired }\end{array}$ & $31(2.80 \%)$ & $25(80.6)$ & $6(19.4)$ & Ref & -- \\
\hline \multicolumn{6}{|l|}{ Family size } \\
\hline Less than 5 & $905(80.4 \%)$ & $661(73.0)$ & $244(27.0)$ & $\begin{array}{c}0.75 \\
(0.55-1.04)\end{array}$ & 0.088 \\
\hline $\begin{array}{l}\text { More than } \\
\text { equal to } 5\end{array}$ & $220(19.6 \%)$ & $148(67.3)$ & $72(32.7)$ & $\operatorname{Ref}$ & -- \\
\hline \multicolumn{6}{|l|}{ Per capita } \\
\hline Upper class & $304(27.0 \%)$ & $205(67.4)$ & $99(32.6)$ & $\begin{array}{c}0.16 \\
(0.01-1.56) \\
\end{array}$ & 0.116 \\
\hline $\begin{array}{l}\text { Upper middle } \\
\text { class }\end{array}$ & $491(43.6 \%)$ & $361(73.5)$ & $130(26.5)$ & $\begin{array}{c}0.12 \\
(0.01-1.16) \\
\end{array}$ & 0.067 \\
\hline
\end{tabular}


medRxiv preprint doi: https://doi.org/10.1101/2020.11.28.20240358; this version posted January 3, 2021. The copyright holder for this preprint (which was not certified by peer review) is the author/funder, who has granted medRxiv a license to display the preprint in perpetuity.

It is made available under a CC-BY-NC-ND 4.0 International license .

\begin{tabular}{|c|c|c|c|c|c|}
\hline Middle class & $263(23.4 \%)$ & $198(75.3)$ & $65(24.7)$ & $\begin{array}{c}0.10 \\
(0.01-1.07) \\
\end{array}$ & 0.057 \\
\hline $\begin{array}{l}\text { Lower middle } \\
\text { class }\end{array}$ & $63(5.6 \%)$ & $44(69.8)$ & $19(30.2)$ & $\begin{array}{c}0.14 \\
(0.01-1.47)\end{array}$ & 0.104 \\
\hline Lower class & $4(0.4 \%)$ & $1(25.0)$ & $3(75.0)$ & Ref & -- \\
\hline \multicolumn{6}{|l|}{ Chronic disease } \\
\hline Yes & $288(25.6 \%)$ & $178(61.8)$ & $110(38.2)$ & $\begin{array}{c}1.89 \\
(1.42-2.51) \\
\end{array}$ & $\begin{array}{c}<0.00 \\
1\end{array}$ \\
\hline No & $837(74.4 \%)$ & $631(75.4)$ & 206 (24.6) & $\operatorname{Ref}$ & -- \\
\hline \multicolumn{6}{|l|}{ Addiction } \\
\hline No & $757(67.3 \%)$ & $547(72.3)$ & $210(27.7)$ & $\begin{array}{c}0.94 \\
(0.72-1.25)\end{array}$ & 0.710 \\
\hline Yes & $368(32.7 \%)$ & $262(71.2)$ & $106(28.8)$ & $\operatorname{Ref}$ & -- \\
\hline \multicolumn{6}{|l|}{$\begin{array}{l}\text { Availability of public } \\
\text { exercise area }\end{array}$} \\
\hline Yes & $995(88.4 \%)$ & $716(72.0)$ & $279(28.0)$ & $\begin{array}{c}0.97 \\
(0.65-1.46) \\
\end{array}$ & 0.920 \\
\hline No & $130(11.6 \%)$ & $93(71.5)$ & $37(28.5)$ & Ref & -- \\
\hline \multicolumn{6}{|l|}{$\begin{array}{l}\text { Distance from } \\
\text { nearest exercise area } \\
(\mathrm{n}=995)\end{array}$} \\
\hline $\begin{array}{l}\text { Up to } 500 \\
\text { meters }\end{array}$ & $726(64.5 \%)$ & $522(71.9)$ & $204(28.1)$ & $\begin{array}{c}1.01 \\
(0.74-1.38) \\
\end{array}$ & 0.946 \\
\hline $\begin{array}{l}\text { More than } \\
500 \text { meters }\end{array}$ & $269(23.9 \%)$ & $194(72.1)$ & 75 (27.9) & $\operatorname{Ref}$ & -- \\
\hline \multicolumn{6}{|l|}{$\begin{array}{l}\text { Behavioural stage } \\
\text { (Based on Prochaska } \\
\text { scale) }\end{array}$} \\
\hline Dynamic & $1046(93.0 \%)$ & $801(76.6)$ & $245(23.4)$ & $\begin{array}{c}0.03 \\
(0.01-0.07) \\
\end{array}$ & $\begin{array}{c}<0.00 \\
1\end{array}$ \\
\hline Static & $79(7.0 \%)$ & $8(10.1)$ & $71(89.9)$ & $\operatorname{Ref}$ & -- \\
\hline \multicolumn{6}{|l|}{ Sitting duration/week } \\
\hline$<6$ hrs/week & $624(55.5 \%)$ & $454(72.8)$ & $170(27.2)$ & $\begin{array}{c}0.91 \\
(0.70-1.18) \\
\end{array}$ & 0.481 \\
\hline$\geq 6 \mathrm{hrs} /$ week & $501(44.5 \%)$ & $355(70.9)$ & $146(29.1)$ & Ref & -- \\
\hline \multicolumn{6}{|l|}{$\begin{array}{l}\text { Practice of Yogasana } \\
(n=1079)\end{array}$} \\
\hline Yes & $179(15.9 \%)$ & $102(60.0)$ & $68(40.0)$ & $\begin{array}{c}2.02 \\
(1.44-2.85) \\
\end{array}$ & $\begin{array}{c}<0.00 \\
1\end{array}$ \\
\hline No & $900(80.0 \%)$ & $684(75.2)$ & $225(24.8)$ & $\operatorname{Ref}$ & -- \\
\hline
\end{tabular}

Univariate analysis:

Caste, Educational attainment, Chronic disease, Stage of change and practice of yogasana are found to be associated with physical activity. Whereas, gender, religion, marital status, SES, employment status, family size, addiction, cumulative sitting duration, presence of 
medRxiv preprint doi: https://doi.org/10.1101/2020.11.28.20240358; this version posted January 3, 2021. The copyright holder for this preprint (which was not certified by peer review) is the author/funder, who has granted medRxiv a license to display the preprint in perpetuity.

It is made available under a CC-BY-NC-ND 4.0 International license .

neighbourhood public exercise facility or availability of neighbourhood exercise facility within 500 meters do not have any association with physical activity (Table 1).

Table 2. Binomial logistic regression analysis of different factors associated with physical activity.

\begin{tabular}{|c|c|c|c|c|c|}
\hline Variables & $\begin{array}{c}\text { Adjusted } \\
\text { Odds ratio }\end{array}$ & $95 \% \mathrm{CI}$ & Beta & SE of Beta & P-value \\
\hline \multicolumn{6}{|l|}{ Age } \\
\hline $18-29$ years & 0.71 & $0.42-1.21$ & -0.336 & 0.269 & 0.211 \\
\hline 30-39 years & 0.66 & $0.40-1.09$ & -0.412 & 0.257 & 0.108 \\
\hline 40-49 years & 0.87 & $0.54-1.42$ & -0.130 & 0.246 & 0.598 \\
\hline 50-59 years & Ref & - & - & - & \\
\hline \multicolumn{6}{|l|}{ Caste } \\
\hline General & 1.43 & $1.03-1.99$ & 0.363 & 0.168 & 0.031 \\
\hline Reserved & Ref & - & - & - & - \\
\hline \multicolumn{6}{|l|}{ Education } \\
\hline Above graduation & 1.30 & $0.71-2.37$ & 0.266 & 0.306 & 0.385 \\
\hline Up to graduation & 1.25 & $0.86-1.82$ & 0.228 & 0.191 & 0.233 \\
\hline Up to High school & Ref & - & - & - & - \\
\hline \multicolumn{6}{|l|}{ Employment status } \\
\hline Gainfully employed & 1.41 & $0.46-4.34$ & 0.349 & 0.568 & 0.538 \\
\hline $\begin{array}{l}\text { Non-gainfully } \\
\text { employed }\end{array}$ & 1.81 & $0.60-5.49$ & 0.596 & 0.565 & 0.292 \\
\hline Unemployed/retired & $\operatorname{Ref}$ & - & - & - & - \\
\hline \multicolumn{6}{|l|}{ Family size } \\
\hline Less than 5 & 0.79 & $0.52-1.20$ & -0.228 & 0.212 & 0.282 \\
\hline More than equal to 5 & Ref & - & - & - & - \\
\hline \multicolumn{6}{|l|}{ SES } \\
\hline Upper class & 0.000 & -- & -18.651 & 22112.16 & 0.999 \\
\hline Upper middle & 0.000 & -- & -18.739 & 22112.16 & 0.999 \\
\hline Middle & 0.000 & -- & -18.729 & 22112.16 & 0.999 \\
\hline Lower middle class & 0.000 & -- & -18.615 & 22112.16 & 0.999 \\
\hline Lower class & Ref & - & - & - & - \\
\hline \multicolumn{6}{|l|}{ Chronic disease } \\
\hline Yes & 2.08 & $1.46-2.98$ & 0.736 & 0.183 & 0.000 \\
\hline No & Ref & - & - & - & - \\
\hline \multicolumn{6}{|l|}{ Prochaska scale } \\
\hline Dynamic & 0.02 & $0.01-0.05$ & -3.774 & 0.450 & 0.000 \\
\hline Static & Ref & - & - & - & - \\
\hline \multicolumn{6}{|l|}{ Practice of Yogasana } \\
\hline Yes & 1.97 & $1.35-2.89$ & 0.682 & 0.195 & 0.000 \\
\hline No & Ref & - & - & - & - \\
\hline
\end{tabular}


medRxiv preprint doi: https://doi.org/10.1101/2020.11.28.20240358; this version posted January 3, 2021. The copyright holder for this preprint (which was not certified by peer review) is the author/funder, who has granted medRxiv a license to display the preprint in perpetuity.

It is made available under a CC-BY-NC-ND 4.0 International license .

variables with a p-value of less than 0.20 were included in the logistic regression analysis. Omnibus tests showed a chi-squared value for model co-efficient of 201.85, with a p-value of $<0.001$. Nagelkerke $R^{2}$ value was 0.247 .

Multivariate analysis:

After adjusting for confounding factors social caste, chronic disease status, practice of yogasana and stage of change were found to be associated with physical activity. Caste, chronic disease status, practice of yogasana were the positive predictors whereas stage of change was found to be a negative predictor of physical activity in our study. General caste had 1.43 times higher odds of being physically active compared to reserved which was statistically significant (95\% CI: $1.03-1.99, \mathrm{P}=0.031)$. Respondents with chronic disease and practice of yogasana had higher odds of being physically active i.e. 2.08 (95\% CI: $1.46-$ 2.98) and 1.97 (95\% CI: 1.35 - 2.89) respectively. Dynamic stage of change of exercise behaviour had lower odds of being physically active i.e. 0.02 (95\% CI: $0.01-0.05)$. A physically active person in Bhubaneswar was more likely from general caste, having some form of chronic disease, in the static stage of change and a yogasana practitioner. Age, education, employment status, family size and SES did not exhibit any association with physical activity status (Table 2).

Table 3: Association of physical inactivity and chronic diseases $(n=1125)$

\begin{tabular}{lccccc}
\hline Variables & $\begin{array}{c}\text { Adjusted Odds } \\
\text { ratio }\end{array}$ & $\mathbf{9 5 \%}$ CI & Beta & SE of Beta & P-value \\
\hline Physically inactive & 1.54 & $1.004-2.382$ & 0.436 & 0.220 & 0.048 \\
\hline
\end{tabular}

IPTW analysis:

Physically inactive subjects have higher odds (adjusted OR $=1.54$ ) of having chronic disease (Table 3). Prior established determinants of the chronic disease are considered for our analysis i.e. age, gender, behaviour, marital status, education, occupation, neighbourhood 
medRxiv preprint doi: https://doi.org/10.1101/2020.11.28.20240358; this version posted January 3, 2021. The copyright holder for this preprint

characteristics (Presence of common exercise area), addiction, sitting time. Inverse probability of treatment weighing method (IPTW) and later generalized estimating equations (GEE) was used to explore the causal association between physical inactivity and chronic diseases based on above mentioned factors.

\section{Discussion}

The study had a uniform representation of the study population of the urban city. There was no inclusion bias for gender as was seen during analysis ( $>>0.05)$. The main results of the study show that the over-all level of PA undertaken by the general public in Bhubanewar is low. A mere $28.1 \%$, (316/1125) participants were found to be physically active as measured by the IPAQ- short form. These scores are low compared to a work that reported $38.3 \%$ of the population to indulge in sufficient PA in India (29). Another international work that assessed PA from different countries found that only $9.3 \%$ men and $15.2 \%$ women are physically inactive (28) in India. However, another study conducted in an urban city in South India reported $49.7 \%$ prevalence of physical inactivity in a sample of 286 adults as measured by the WHO standard Global Physical Activity Questionnaire [41]. On the contrary, the results from a market intelligence agency showed that $64 \%$ Indians in a sample of 3000 adults aged 18 and above do not exercise [42]. This inconsistency in reporting PA prevalence patterns in India are perplexing. We hypothesize this to be attributed to the study population, location of study (urban/ rural), type of questionnaire used to document PA or there may be rapidly growing physical inactivity in the Urban Odisha.

Another alarming result that we found from our study was the $25.6 \%$ prevalence rate of participants suffering from at least a chronic disease. A recent work estimated the overall prevalence of diabetes, hypertension, and obesity in India as $2.9 \%, 14.4 \%$ and $9.7 \%$, 
medRxiv preprint doi: https://doi.org/10.1101/2020.11.28.20240358; this version posted January 3, 2021. The copyright holder for this preprint

respectively [43]. The results of our study showed that persons who suffer from chronic disorders are at increased odds of engaging in a regular PA program. This either we hypothesize to the prescription or advice by HCPs to participate in PA or the participants might have started doing exercises understanding the benefits of PA. This is in contrary to previous results which found that the activity limitations increases with the number of chronic conditions and reduces the amount of PA undertaken in people with chronic disorders[44,45].

$368(32.7 \%)$ of the participants self-reported to be addicted to illicit substances that are identified as risk factors that contribute to non-communicable diseases. This number $(32.7 \%)$ is higher than the combined risk factors (alcohol use and tobacco use) provided in the 2014 report on global status of non-communicable diseases [46]. Studies have shown mixedresults regarding the association between substance abuse and PA. One study reported positive association of PA with current and future alcohol use but negative association with tobacco and other drug use [47]. Literature consistently reports that PA is inversely associated with tobacco use in adults and physically active adults are more likely to be moderate drinkers $[48,49]$.

Our study results show that while education can influence PA pattern individually, the role of education seems to be silent when controlled for other sociodemographic factors. We hypothesize this to the role of perceived self-control executed by education on behavioural change [50]. Persons with low perceived control are found to lack confidence, and neither do not work for positive intended outcomes nor work towards elimination of undesired outcomes [51]. The study limitations such as having more than $50 \%$ study participants who were educated till graduation level, PA was self-reported and was not reporting any longterm status change, the period of data collection was immediately before COVID-pandemic 
medRxiv preprint doi: https://doi.org/10.1101/2020.11.28.20240358; this version posted January 3, 2021. The copyright holder for this preprint

with not so good national and global economic conditions might have played a role in the study period between predictors.

The results also showed that being in the dynamic stage of Prochaska stage of change was found to negatively predict PA. This scale describes how the attitude changes based on the duration of behavior change [51]. The reasons for the negative predictions are beyond the scope of study. However, past works have shown that such changes to be more effective in participants who are already assigned to an intervention, or in those who with pre-existing health disorders who have been assigned to an intervention [52-55].

The results that physically inactive participants have higher odds of having chronic disease are not surprising. PA is touted as a primary preventive measure from chronic disorders and fosters wellness in general [56-58]. PA also prevents the progression of symptomatic diseases and delay its progression to disability, or death [58,59].

Our data also showed a reduction in the duration and intensity of walking as measured by our study participants. The over-all walking percentage by humans have reduced by $50-70 \%$ and a mean cadence of 7473 steps has been reported from 26 studies conducted between 19662007 [60,61]. Normative data indicates that normal adults walk between 4,000 and 18,000 steps/day; and 10,000 steps/day are considered as reasonable cadence per day. Literature suggests that efforts have to be initiated to increase the walking to a minimum of $2,000-2,500$ steps/day [62].

$15.9 \%$ of our study respondents reported practicing yoga. Our figures are way higher than the $5.3 \%$ and $11.8 \%$ reported by a previous work in the eastern zone and pan-India respectively [62].The increased awareness could be attributed to the roots of yoga's origins that can be traced to India and the national promotion towards celebration of International Day of Yoga and follow yoga as a daily part of life. The study results showed that those who practised yoga had 2.02 times higher odds of being physically active. This may be attributed to the role 
medRxiv preprint doi: https://doi.org/10.1101/2020.11.28.20240358; this version posted January 3, 2021. The copyright holder for this preprint

of yoga in increasing self-efficacy and intrinsic motivation, which may encourage persons to engage in PA [63]. Though it may be argued that subtle differences exist between physical exercises and the physical components of yoga practices, the results of our study shows yoga can be an effective and feasible alternative to PA.

Amongst other factors studied, multivariate analysis indicated that general caste had 1.43 times higher odds being physically active, when controlled for confounding factors. Social caste is a marker of socio-economic status [64] in India. Populations other than the general caste category fall into reserved caste and they represent the underserved population. Past work has reported that underserved populations were less likely to participate in sufficient moderate to vigorous PA [65].

There are some limitations to this study. For assessment of physical activity, IPAQ- short form was used, which is a self-reporting measure. The risks of recall bias leading to over- or under-reporting of PA cannot be ruled out and future works may consider using objective measures of PA, such as pedometers or accelerometers. Further, IPAQ is criticized for overestimating PA prevalence in population surveys [66]. Future studies may evaluate the associations between PA prevalence measured by IPAQ, GPAQ and objective measures. Though a representative population has been sampled, the results may be generalized to other urban places but not relevant to rural areas. Considering the differences in PA prevalence between the results of this study and other previous works, efforts should be made to study the national estimate using a common protocol.

\section{Conclusion:}


Prevalence of physically activity was found to be $28.1 \%$ out of which only $1 \%$ were involved in high level of Physical activity. 15.9\% practised 'yogasana', with $32.8 \%$ of them meeting recommended standards of physical activity. General caste, already having a chronic disease, being in the static stage of change and a yogassana practitioner were all factors which made more likely for a person to be physically active. Physically inactive individuals were also found to have 1.54 times higher odds of having chronic disease than those who are physically active.

Source of funding: None

Conflicts of interest: None

\section{References:}

1 Caspersen C, Powell K, Christenson G. Physical activity, exercise, and physical fitness: definitions and distinctions for health-related research. Public Health Rep 1985;100:126-31. doi:10.2307/20056429

2 Center of Disease Control and Prevention- USA. Physical activity and Health - A report of surgeon general (Executive Summary).

3 WHO. Global strategy on diet, physical activity and health.Report by the Secretariat. Geneva, World Health Orga-nization. 2004.

$4 \quad$ World Heath Organization. Global Health Risks. 2009.

5 Ferrucci L, Izmirlian G, Leveille S, et al. Smoking, physical activity, and active life expectancy. Am J Epidemiol 1999;149:645-53.

doi:10.1093/oxfordjournals.aje.a009865

6 World Heath Organization. Physical Inactivity: A Global Public Health Problem. 2015. 
medRxiv preprint doi: https://doi.org/10.1101/2020.11.28.20240358; this version posted January 3, 2021. The copyright holder for this preprint (which was not certified by peer review) is the author/funder, who has granted medRxiv a license to display the preprint in perpetuity.

It is made available under a CC-BY-NC-ND 4.0 International license .

7 World Heath Organization. Physical activity. Glob. Heal. Obs. data.

2016.https://www.who.int/gho/ncd/risk_factors/physical_activity_text/en/ (accessed 2 Jul 2020).

8 Abu-Omar K, Rütten A. [Physical activity and public health]. Bundesgesundheitsblatt Gesundheitsforsch Gesundheitsschutz 2012 Jan;55(1)66-72 doi 101007/s00103-0111389-8 Published Online First: 2012. doi:10.1007/s00103-011-1389-8

9 Kohl H, Lynn C, Victoria E, et al. The pandemic of physical inactivity: global action for public health. Lancet 2012;380:294-305. doi:10.1016/S0140-6736(12)60898-8

10 Anjana RM, Pradeepa R, Das AK, et al. Physical activity and inactivity patterns in India - results from the ICMR-INDIAB study (Phase-1) [ICMR-INDIAB-5]. Int $J$ Behav Nutr Phys Act 2014;11:26. doi:10.1186/1479-5868-11-26

11 Ganesh GS, Patel R, Dwivedi V, et al. Leisure time physical activity patterns in Odisha, India. Diabetes Metab Syndr Clin Res Rev 2018;12:227-34. doi:10.1016/j.dsx.2017.09.009

12 Ross A, Thomas S. The health benefits of yoga and exercise: a review of comparison studies. J Altern Complement Med 2010;16:3-12. doi:10.1089/acm.2009.0044

13 Semwal DK, Chauhan A, Mishra SP. Recent Development in Yoga $\square$ : A Scientific Perspective. J AYUSH Ayurveda, Yoga, Unani, Siddha Homeopath 2016;5:14.

14 Field T. Yoga clinical research review. Complement Ther Clin Pr 2011;17:1-8. doi:10.1016/j.ctcp.2010.09.007

15 Ministry of youth affairs and sports (GOI). Fit India. 2019.

16 Ministry of youth affairs and sports (GOI). Khelo India. 2019.

17 Dishman RK, Sallis JF, Orenstein DR. The determinants of physical activity and exercise. Public Health Rep 1985;100:158-

71.https://www.ncbi.nlm.nih.gov/pmc/articles/PMC1424729/ 
medRxiv preprint doi: https://doi.org/10.1101/2020.11.28.20240358; this version posted January 3, 2021. The copyright holder for this preprint (which was not certified by peer review) is the author/funder, who has granted medRxiv a license to display the preprint in perpetuity.

It is made available under a CC-BY-NC-ND 4.0 International license .

18 Aleksovska K, Puggina A, Giraldi L, et al. Biological determinants of physical activity across the life course: A "determinants of diet and physical activity" (DEDIPAC) umbrella systematic literature review. Sport Med - Open 2019;5:1-18.

doi:10.1186/s40798-018-0173-9

19 National Ageing Research Institute (Australian Government). National physical activity recommendations for older Australians $\square$ : Discussion Document. 2006. https://www1.health.gov.au/internet/publications/publishing.nsf/Content/phd-physicalrec-older-disc $\sim$ chapter-5

20 Justine M, Azizan A, Hassan V, et al. Barriers to participation in physical activity and exercise among middle-aged and elderly individuals. Singapore Med J 2013;54:581-6. doi:10.11622/smedj.2013203

21 Mathews E, Lakshmi JK, Ravindran TKS, et al. Perceptions of barriers and facilitators in physical activity participation among women in Thiruvananthapuram City, India.

Glob Health Promot 2016;23:27-36. doi:10.1177/1757975915573878

22 Lovell GP, Ansari W El, Parker JK. Perceived exercise benefits and barriers of nonexercising female university students in the United Kingdom. Int J Environ Res Public Health 2010;7:784-98. doi:10.3390/ijerph7030784

23 Aljayyousi G, Munshar M, Al-Salim F, et al. Addressing context to understand physical activity among Muslim university students: the role of gender, family, and culture. BMC Public Heal 2019;19:1452. doi:10.1186/s12889-019-7670-8

24 Pati S, Sinha R, Mahapatra P. Non-communicable Disease Risk Reduction Teaching in India: A Curricular Landscape. Front Public Heal 2019;4:133. doi:doi: 10.3389/fpubh.2019.00133.

25 World Heath Organization. Non-communicable Diseases Progress Monitor. 2017.http://apps.who.int/iris/bitstream/handle/10665/258940/9789241513029- 
medRxiv preprint doi: https://doi.org/10.1101/2020.11.28.20240358; this version posted January 3, 2021. The copyright holder for this preprint (which was not certified by peer review) is the author/funder, who has granted medRxiv a license to display the preprint in perpetuity.

It is made available under a CC-BY-NC-ND 4.0 International license .

eng.pdf?sequence $=1($ accessed 15 Oct 2020).

26 Kinra S, Bowen L, Lyngdoh T, et al. Sociodemographic patterning of non-

communicable disease risk factors in rural India: a cross sectional study. $B M J$

2010;27:c4947. doi:doi: 10.1136/bmj.c4974

27 Gupta R, Joshi P, Mohan V, et al. Epidemiology and causation of coronary heart disease and stroke in India. Heart 2008;94:16-26. doi:10.1136/hrt.2007.132951

28 Anand G, Deb A. Planning, Violations, and Urban Inclusion $\square$ : A Study of

Bhubaneswar. 2017. http://iihs.co.in/knowledge-gateway/wp-

content/uploads/2017/11/Bhubaneswar-Final.pdf

29 Bhubaneswar municipal corporation. Bhubaneswar population census 2011-2020.

2011.https://www.census2011.co.in/data/town/801859-bhubaneswar-orissa.html

30 Anjana RM, Pradeepa R, Das AK, et al. Physical activity and inactivity patterns in

India - results from the ICMR-INDIAB study. Int J Behav Nutr Phys Act 2014;11:1-

11. doi:10.1186/1479-5868-11-26

31 Varo Cenarruzabetia JJ, Martínez González MA, Sánchez-Villegas A, et al. Attitudes and practices regarding physical activity: Situation in Spain with respect to the rest of Europe. Aten Primaria 2003;31:77-84. doi:10.1016/S0212-6567(03)79141-0

32 Youthrex. International Physical Activity Questionnaire - Short Form. PLOS. 2002.https://journals.plos.org/plosone/article/file?type=supplementary\&id=info:doi/10 .1371/journal.pone.0219193.s010 (accessed 20 Jun 2018).

33 Richa Hirendra Rai, Mohd Asif NM. RELIABILITY OF INTERNATIONAL PHYSICAL ACTIVITY QUESTIONNAIRE - SHORT FORM IPAQ-SF FOR YOUNG ADULTS IN INDIA | Rai | European Journal of Physical Education and Sport Science. Eur J Phys Educ Sport 2018;5:146-57.

doi:doi.org/10.5281/zenodo.2222256 
medRxiv preprint doi: https://doi.org/10.1101/2020.11.28.20240358; this version posted January 3, 2021. The copyright holder for this preprint (which was not certified by peer review) is the author/funder, who has granted medRxiv a license to display the preprint in perpetuity.

It is made available under a CC-BY-NC-ND 4.0 International license .

34 Tran V, Do V, Pham N, et al. Validity of the International Physical Activity Questionnaire-Short Form for Application in Asian Countries: A Study in Vietnam. Eval Health Prof 2018;43:105-9. doi:https://doi.org/10.1177/0163278718819708

35 Lee PH, Macfarlane DJ, Lam TH, et al. Validity of the international physical activity questionnaire short form ( IPAQ-SF ): A systematic review. Int J Behav Nutr Phys Act 2011;8:115. doi:10.1186/1479-5868-8-115

36 Pandey VK, Aggarwal P, Kakkar R. Modified BG Prasad's Socio -economic Classification-2018 $\square$ : The need of an update in the present scenario. Indian $J$ community Heal 2018;30:1-

3.http://www.iapsmupuk.org/journal/index.php/IJCH/article/view/803/803

37 World Health Organization. International statistical classification of diseases and related health problems- 10th revision (ICD-10). 2016.

http://www.who.int/classifications/icd/icdonlineversions/en/

38 Prochaska J, Di Clemente C. Transtheoretical Therapy: Towards a more integrative model of change. Psychother Theory, Res Pract 1982;19:276-88. doi:0033-3204

39 Guthold R, Ono T, Strong KL, et al. Worldwide Variability in Physical Inactivity. A 51-Country Survey. Am J Prev Med 2008;34:486-94.

doi:10.1016/j.amepre.2008.02.013

40 Bauman A, Bull F, Chey T, et al. The international prevalence study on physical activity: Results from 20 countries. Int J Behav Nutr Phys Act 2009;6:1-11. doi:10.1186/1479-5868-6-21

41 Newtonraj A, Murugan N, Singh Z, et al. Factors associated with physical inactivity among adult urban population of Puducherry, India: A population based crosssectional study. J Clin Diagnostic Res 2017;11:LC15-7. doi:10.7860/JCDR/2017/24028.9853 
medRxiv preprint doi: https://doi.org/10.1101/2020.11.28.20240358; this version posted January 3, 2021. The copyright holder for this preprint (which was not certified by peer review) is the author/funder, who has granted medRxiv a license to display the preprint in perpetuity.

It is made available under a CC-BY-NC-ND 4.0 International license .

42 The Times Of India. 64 per cent Indians don’t exercise. Artic. show/70038656.cms. 2019.https://timesofindia.indiatimes.com/life-style/health-fitness/health-news/64-percent-indians-dont-exercise-study/articleshow/70038656.cms (accessed 30 Oct 2020).

43 Corsi DJ, Subramanian S V. Socioeconomic Gradients and Distribution of Diabetes, Hypertension, and Obesity in India. JAMA Netw open 2019;2:e190411.

doi:10.1001/jamanetworkopen.2019.0411

44 Warshaw G. Introduction: Advances and Challenges in Care of Older People with Chronic Illness. Generations 2006;30:5-10.https://www.questia.com/read/1P31266202761/introduction-advances-and-challenges-in-care-of-older (accessed 2 Nov 2020).

45 Lee WC, Ory MG. The engagement in physical activity for middle-aged and older adults with multiple chronic conditions: Findings from a community health assessment. J Aging Res Published Online First: 2013. doi:10.1155/2013/152868

46 World Heath Organization. Global status report on noncommunicable diseases- 2014. World Health Organization 2014. http://www.who.int/nmh/publications/ncd-statusreport-2014/en/ (accessed 2 Nov 2020).

47 Brellenthin AG, Lee D. Physical Activity and the Development of Substance Use Disorders. Prog Prev Med 2018;3:e0018. doi:10.1097/pp9.0000000000000018

48 Leasure JL, Neighbors C, Henderson CE, et al. Exercise and alcohol consumption: What we know, what we need to know, and why it is important. Front. Psychiatry. 2015;6:156. doi:10.3389/fpsyt.2015.00156

49 Auer R, Vittinghoff E, Kiefe C, et al. Change in physical activity after smoking cessation: The Coronary Artery Risk Development in Young Adults (CARDIA) study. Addiction 2014;109:1172-83. doi:10.1111/add.12561

50 Skinner EA. A guide to constructs of control. J Pers Soc Psychol 1996;71:549-70. 
medRxiv preprint doi: https://doi.org/10.1101/2020.11.28.20240358; this version posted January 3, 2021. The copyright holder for this preprint (which was not certified by peer review) is the author/funder, who has granted medRxiv a license to display the preprint in perpetuity.

It is made available under a CC-BY-NC-ND 4.0 International license .

doi:10.1037//0022-3514.71.3.549

51 Thompson SC, Spacapan S. Perceptions of Control in Vulnerable Populations. J Soc Issues 1991;47:1-21. doi:10.1111/j.1540-4560.1991.tb01831.x

52 Dallow CB, Anderson J. Using self-efficacy and a transtheoretical model to develop a physical activity intervention for obese women. Am J Heal Promot 2003;17:373-81. doi:10.4278/0890-1171-17.6.373

53 Shirazi KK, Wallace LM, Niknami S, et al. A home-based, transtheoretical change model designed strength training intervention to increase exercise to prevent osteoporosis in Iranian women aged 40-65 years: A randomized controlled trial. Health Educ Res 2007;22:305-17. doi:10.1093/her/cyl067

54 Opdenacker J, De Bourdeaudhuij I, Auweele Y Vanden, et al. Psychosocial mediators of a lifestyle physical activity intervention in women. Psychol Sport Exerc 2009;10:595-601. doi:10.1016/j.psychsport.2009.03.002

55 Glanz K, Rimer B, Viswanath K. Health behavior and health education: theory, research, and practice. New York: : Jossey-Bass 2008.

56 Hahn RA, Teutsch SM, Rothenberg RB, et al. Excess Deaths From Nine Chronic Diseases in the United States, 1986. JAMA J Am Med Assoc 1990;264:2654-9. doi:10.1001/jama.1990.03450200062032

57 Mokdad AH, Marks JS, Stroup DF, et al. Actual Causes of Death in the United States, 2000. J. Am. Med. Assoc. 2004;291:1238-45. doi:10.1001/jama.291.10.1238

58 Katz DL, Ali A. Preventive medicine, integrative medicine \& the health of the public. In: Summit on Integrative Medicine and the Health of the Public.v. 2009. 45.https://www.researchgate.net/publication/237429179_Preventive_medicine_integra tive_medicine_and_the_health_of_the_public

59 Katzmarzyk PT, Church TS, Craig CL, et al. Sitting time and mortality from all 
medRxiv preprint doi: https://doi.org/10.1101/2020.11.28.20240358; this version posted January 3, 2021. The copyright holder for this preprint (which was not certified by peer review) is the author/funder, who has granted medRxiv a license to display the preprint in perpetuity.

It is made available under a CC-BY-NC-ND 4.0 International license .

causes, cardiovascular disease, and cancer. Med Sci Sports Exerc 2009;41:998-1005.

doi:10.1249/MSS.0b013e3181930355

60 Bravata DM, Smith-Spangler C, Sundaram V, et al. Using pedometers to increase physical activity and improve health: A systematic review. J. Am. Med. Assoc. 2007;298:2296-304. doi:10.1001/jama.298.19.2296

61 O’ Keefe JH, Vogel R, Lavie CJ, et al. Achieving hunter-gatherer fitness in the 21st century: Back to the future. Am. J. Med. 2010;123:1082-6.

doi:10.1016/j.amjmed.2010.04.026

62 Tudor-Locke C, Craig CL, Brown WJ, et al. How many steps/day are enough? for adults. Int J Behav Nutr Phys Act 2011;8. doi:10.1186/1479-5868-8-79

63 Martin EC, Dick AM, Scioli-Salter ER, et al. Impact of a yoga intervention on physical activity, self-efficacy, and motivation in women with PTSD symptoms. $J$ Altern Complement Med 2015;21:327-32. doi:10.1089/acm.2014.0389

64 Corsi DJ, Subramanian S V. Association between socioeconomic status and selfreported diabetes in India: A cross-sectional multilevel analysis. BMJ Open 2012;2:112. doi:10.1136/bmjopen-2012-000895

65 Mendoza-Vasconez A, Likne S, Munoz M, et al. Promoting Physical Activity among Underserved Populations. Curr Sport Med Rep 2016 Jul-Aug;15(4)290-7 doi 101249/JSR0000000000000276 Published Online First: 2016. doi:10.1249/JSR.0000000000000276

66 Ainsworth BE, Macera CA, Jones DA, et al. Comparison of the 2001 BRFSS and the IPAQ physical activity questionnaires. Med Sci Sports Exerc 2006;38:1584-92. doi:10.1249/01.mss.0000229457.73333.9a 
medRxiv preprint doi: https://doi.org/10.1101/2020.11.28.20240358; this version posted January 3, 2021. The copyright holder for this preprint (which was not certified by peer review) is the author/funder, who has granted medRxiv a license to display the preprint in perpetuity.

\author{
It is made available under a CC-BY-NC-ND 4.0 International license.
}

